\title{
Breeding records of Leptotila rufaxilla (Aves: Columbidae) in southwestern Brazilian Amazon with notes on nesting in some regions of occurrence
}

\section{Registros de reproducción de Leptotila rufaxilla (Aves: Columbidae) en el suroeste de la Amazonia brasileña con notas sobre anidación en algunas regiones de ocurrencia}

\section{Jônatas Lima* \\ https://orcid.org/0000-0002-9663-5208 \\ jonatasornito@gmail.com \\ Railene Almeida \\ https://orcid.org/0000-0001-8038-9252 \\ rayleneealmeida@gmail.com \\ Edson Guilherme \\ https://orcid.org/0000-0001-8322-1770 \\ guilherme.edson@gmail.com \\ *Corresponding author}

Laboratório de Ornitologia, Centro de Ciências Biológicas e da Natureza, Universidade Federal do Acre, Rio Branco, AC, Brazil.

\section{Citación}

Lima J, Almeida R, Guilherme E. 2021. Breeding records of Leptotila rufaxilla (Aves: Columbidae) in southwestern Brazilian Amazon with notes on nesting in some regions of occurrence. Revista peruana de biología 28(3) e18793 (Agosto 2021). doi: http://dx.doi. org/10.15381/rpb.v28i3.18793

$\begin{array}{ll}\text { Presentado: } & 17 / 09 / 2020 \\ \text { Aceptado: } & 27 / 04 / 2021\end{array}$

Publicado online: $30 / 08 / 2021$

Editor:

Leonardo Romero

\section{Resumen}

Presentamos nuevos aspectos de la biología reproductiva de la Yerutí Colorada Leptotila rufaxilla, de cinco nidos encontrados entre 2012 y 2014 en un fragmento de bosque de tierras bajas en el suroeste de Brasil. Los nidos con forma simple / plataforma se construyeron a una altura media de $1.90 \mathrm{~m}$ sobre el suelo. El tamaño de la puesta fue de dos huevos blancos y elípticos, incubados durante 15 días (basado en tres nidos). Registramos depredación en dos nidos aún en fase de incubación. El peso mínimo al nacer de los pichones fue de $10 \mathrm{~g}$ y los polluelos dejaron el nido con una masa media de $56 \mathrm{~g}$. La tasa de crecimiento constante $(K)$ de los pichones fue de 0.40 con una asíntota de crecimiento de $60.7 \mathrm{~g}$. La tasa de supervivencia diaria, Mayfield y el éxito aparente de anidación en el período de incubación fue de 90,20 y $56 \%$, respectivamente, mientras que en el período de cría fueron todos de $100 \%$. Nuestros datos y el aporte de la ciencia ciudadana mostraron que L. rufaxilla se reproduce durante el año, principalmente en la época de lluvias, tanto en el suroeste de la Amazonia como en otras regiones de ocurrencia.

\section{Abstract}

We present new aspects of breeding biology of Gray-fronted Dove Leptotila rufaxilla, from five nests found between 2012 and 2014 in a lowland forest fragment in southwestern Brazil. The nests simple/platform shape were built at a mean height of $1.90 \mathrm{~m}$ above ground. The clutch size was two eggs white and elliptic, incubated for 15 days (based on three nests). We recorded predation in two nests still in incubation phase. Minimum hatch weight of nestlings was $10 \mathrm{~g}$ and young fledged with a mean mass of $56 \mathrm{~g}$. The constant growth rate $(K)$ of nestlings was 0.40 with a growth asymptote of $60.7 \mathrm{~g}$. Daily survival rate, Mayfield and apparent nesting success in the incubation period was 90,20 and $56 \%$, respectively, while in the nestling period were all $100 \%$. Our data and the contribution of citizen science showed that L. rufaxilla breeds over the year, mainly in the rainy season, both in southwestern Amazonia and in other regions of occurrence.

Palabras claves:

Leptotila rufaxilla; Columbidae; Amazónico; estacionalidad; aves neotropicales; biología reproductora; tamaño del nidada; polluelos; datos de ciencia ciudadana.

Keywords:

Leptotila rufaxilla; Columbidae;Amazonian; seasonality; Neotropical birds; breeding biology; Clutch size; nestlings; citizen-science data. 


\section{Introduction}

Ornithological studies in the Neotropical region have increased considerably in recent years (Xiao et al. 2017), but the basic aspects of the biology of many bird species remain limited. Among them are reproductive aspects, mainly lack of knowledge about nests and eggs (Heming et al. 2013, Jahn et al. 2017). Not all studies of avian breeding biology have given to these aspects the attention of practical and theoretical importance they deserve, such as incubation and nestling period (Skutch 1945).

The Gray-fronted Dove Leptotila rufaxilla ranges widely in South America with six recognized subspecies (Baptista et al. 2020). In Brazil, this species is widely distributed, and four subspecies are recognized (Piacentini et al. 2015). In southwestern Amazon (State of Acre), southeastern Colombia, eastern Ecuador, south Venezuela and north Brazil represent the limit of the distribution of L. r. dubusi (Baptista et al. 2020). In Acre L. rufaxilla inhabits the interior of the forest and is common to occur in open areas with plantations, where occurs in sympatry with its congener L. verreauxi (Guilherme 2016). Few data are available on the reproductive biology of $L$. rufaxilla, with some observations in northern Brazil (Oniki \& Willis 1983), French Guiana (Tostain 1989), Surinam (Ingels 1981), Trinidad (Snow \& Snow 1964) and Argentina (Bodrati \& Salvador 2013, de la Peña 2019). Here we present new information on the breeding biology, such as nestling growth, of L. rufaxilla from a lowland forest in southwestern Brazilian Amazon.

\section{Material and methods}

We conducted fieldwork at the Zoobotanical Park (ZP) (09 $\left.57^{\prime} 08.9^{\prime \prime} \mathrm{S}, 67^{\circ} 52^{\prime} 22.5^{\prime \prime} \mathrm{W}\right)$ of the Federal University of Acre (UFAC), in Rio Branco, Brazilian state of Acre. The ZP is a forest fragment with an area of ca.100 ha surrounded by an urban matrix, and it is one of the largest urban forest fragments of the Rio Branco (Meneses-Filho et al. 1995, Souza et al. 2020). The vegetation is composed of successional forests of varying ages dominated by the cycle of mass mortality and succession of the bamboo Guadua weberbaueri, and dense understory with many vine tangles (Meneses-Filho et al. 1995, Silveira 1999). The region's climate is humid tropical, with a dry season (May-October) and a rainy season (November-April) (Duarte 2006). The avian assemblage of the $\mathrm{ZP}$ is composed by 150 birds species distributed over 36 families, and some species are migratory and others have restricted geographical distribution (Guilherme 2001).

We found the nests during non-systematic observations made between 2012 and 2014. We monitored all nests found, irrespective of stage, until they became inactive. We measured eggs and nestlings using an analogue calliper (0.05 mm precision) and millimeter ruler, respectively. We weighed eggs and nestlings using a Pesola $\AA$ scale with a capacity of $100 \mathrm{~g}$ and accurate to the nearest $1 \mathrm{~g}$. We collected nests after they became inactive and deposited them in the collection of the UFAC ornithology laboratory. We described the nests according to the standardized scheme proposed by Simon and Pacheco (2005).
We calculated the incubation period from the date the last egg was laid until the last chick hatched. Posthatching, we measured the mass of nestlings every two days to minimize our impact on nests. We considered the nestling development period based on the hatching of the first nestling (day 0, see Oniki \& Willis 2001) and the abandonment of the nest by the second chick. We estimated growth following Ricklefs (1967) using the equation:

$$
W(t)=A /(1+e[-K(t-t i)]
$$

Where $\mathrm{W}(t)$ is the mass of the nestling at age $\mathrm{t}, A$ is the asymptote of the growth curve, $K$ is the constant growth rate and $t i$ is the inflection point of the growth curve. We run the equation in the $\mathrm{R}$ software version 3.5.1 (R Core Team 2018). We applied the Mayfield (1961) method to calculate reproductive success rates and determined apparent success as the ratio between the number of successful nests and the total number found (Jehle et al. 2004).

We searched for records of active L. rufaxilla nests, including those with nestlings on the Brazilian Wikiaves site (http://www.wikiaves.com.br/) and eBird site (http://www.ebird.org), up to 29 June 2020. We verified the date, location, the author, and the content of each photograph (nests with eggs or nestlings). For the purposes of the study, we considered all the photographs from all localities, except those of a given nest taken on the same or subsequent days. We compiled a list of the number of records per month over the course of the year, including active nests and nests with nestlings, to determine the period of the species' breeding season. Citizen science plays an especially important role in the compilation of data on the natural history of bird species (Tewksbury et al. 2014, Turnhout et al. 2016).

\section{Results}

We found five nests in ZP (one in February 2012, two in January 2013, one in August, and one in September 2014), which all were active. All nests were constructed in open areas or at the edge of forest on different substrates. Two nests were built in forks of Theobroma grandiflorum (Fig. 1a, b) and three nests in tangled vegetation at the edge of forest, which we did not identify the support plants. On average, nests were placed $1.90 \mathrm{~m}$ above ground (range $1.50-2.50 \mathrm{~m}$ ). We found all nests with eggs. Most nests were built of dry leaves, pliable blades of dry grass, plants tendril and many sticks conformed to the simple / platform type sited in the fork of thin branches or over the accumulation of dry leaves among the vegetation at the forest edge (Figs. 1c, d, e). Mean measurements of nests were height of the external wall $=10 \mathrm{~cm}$ $(n=1)$, diameter $13.5 \pm 2.1 \mathrm{~cm}(12-15 \mathrm{~cm} ; \mathrm{n}=2)$, depth $=3 \pm 1.4 \mathrm{~cm}(2-4 \mathrm{~cm} ; \mathrm{n}=2)$ and mass $=44.61 \mathrm{~g}(\mathrm{n}=1)$.

The clutch size was two eggs in all nests. Eggs were predominantly white and elliptic shape (Fig. 2a). Mean eggs (n =9) mass was $6.1 \pm 1.1 \mathrm{~g}(5-7 \mathrm{~g})$ and size $28.4 \times 20.2 \pm 1.3-$ $0.4 \mathrm{~mm}(27-31 \times 20-21 \mathrm{~mm})$. In nest 5 , female laid eggs in consecutive days. Of all the nests monitored, eggs of nests 2 and 3 were failed to hatch by predation (e.g., Fig. 2b). 

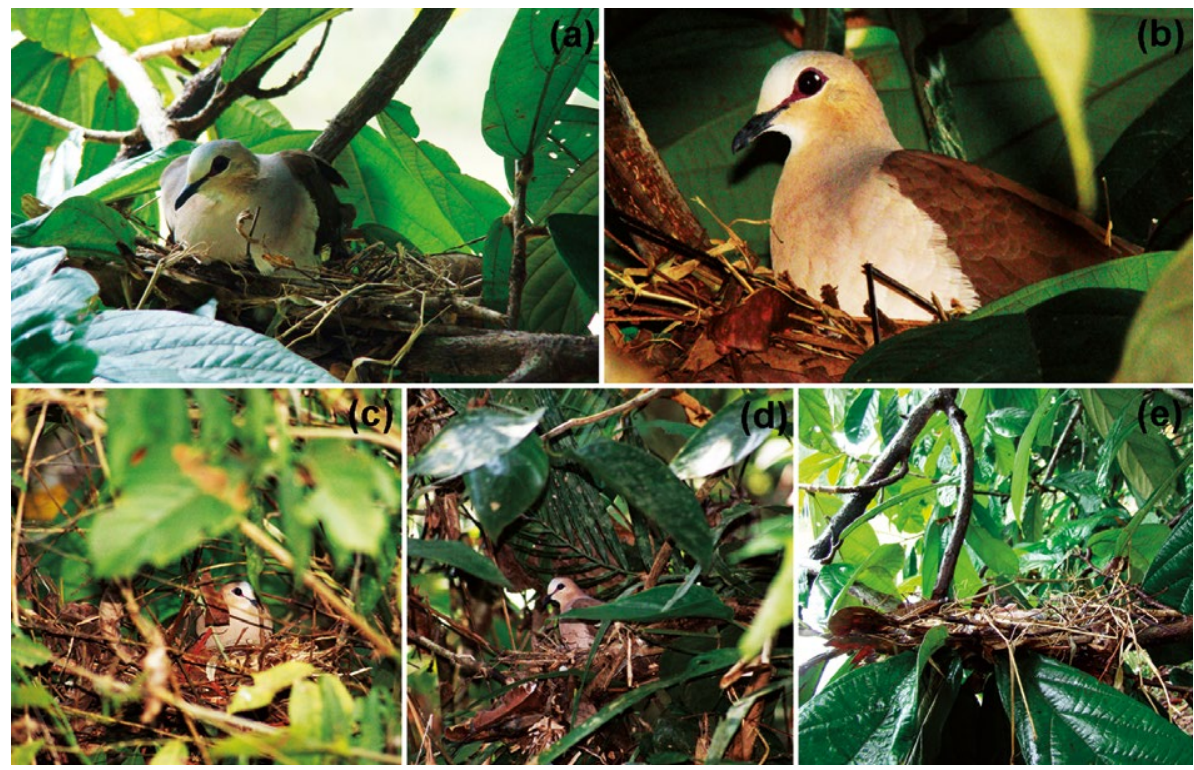

Figure 1. Nests of Leptotila rufaxilla found in a forest fragment in southwestern Amazon. (a,b) Theobroma grandiflorum branch where nests 1 and 2 were sited with an adult incubating. (c,d) Nests 4 and 5 built over the dry vegetation at the edge of forest with an adult incubating. (e) Lateral view of nest shape. Photos: $(a, e)$ RA; (b-d) JL.

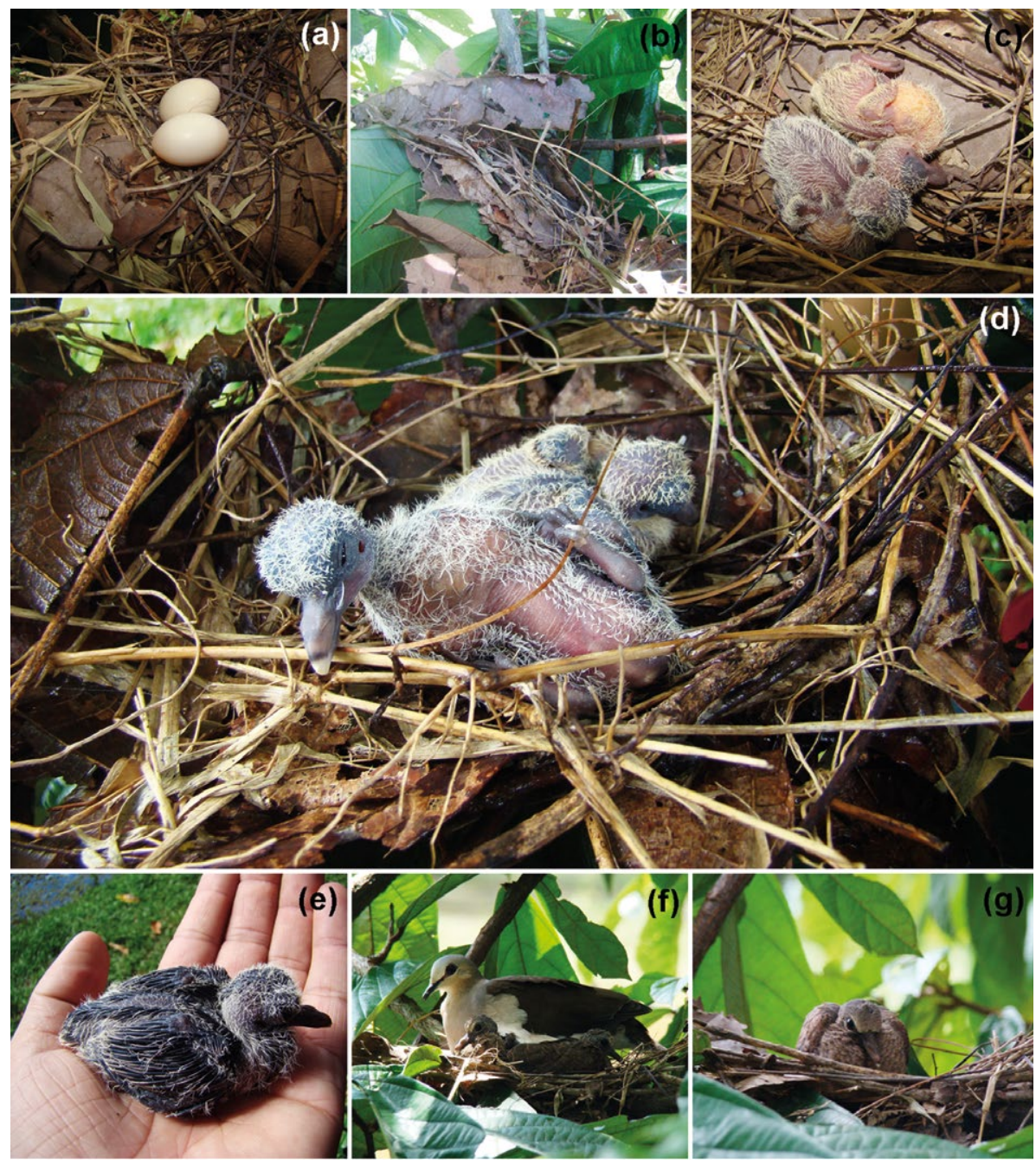

Figure 2. (Nest $1 \mathrm{c}-\mathrm{g}$ ) Development of Leptotila rufaxilla nestlings in a forest fragment in southwestern Amazon. (a) Detail of the eggs in nest 2 and (b) the same nest predated during incubation period. (c) Recently hatched nestling, and (d) five-day-old nestling. (e) Six-day-old and (f) 14-day-old nestling. (g) Nestling with mass of $62 \mathrm{~g}$ in the same date of fledging. Photos: $(a, b) \mathrm{JL} ;(c-g)$ : RA. 
We recorded the longest incubation period of 15 days based in one nest. Daily nest survival rate showed there is $60 \%$ chance that a nest survives from one day to the next. Daily survival rate during the incubation period was $90 \%$. Mayfield success during the incubation period was $20 \%$, assuming duration of 15 days. Apparent success was $56 \%$ in the incubation period.

We monitored the development of five nestlings (two in March 2012, two in September, and one in October 2014) after approximately one and four days from nests 1, 4 and 5 (Fig. 3). Nestlings hatch with dark pink skin, white plumes all over the body and eyes closed (Fig. 2c). After four or five days, the eyes are slightly open, the skin darkens, and the feathers of the remiges start to develop (Fig. 2d). Minimum hatch weight was $10 \pm 2$ $\mathrm{g}(\mathrm{n}=3)(8-12 \mathrm{~g})$, and nestling weight reached a mean 13-29 g after only 4 days, $40 \mathrm{~g}$ on day 6 (Fig. 2e) and $62 \mathrm{~g}$ on day 14 (Fig. 2f, g), the heaviest recorded of any nestling (Fig. 3, Nest 1). All nestlings from nests 4 and 5 were infected with maggots (Diptera) under skin on the head. Chicks fledged after day 14 . One chick from nest 4 fledged with ten days. We ringed three chicks in the nest (codes L-84948, H-84945 and M-29021). The longest nestling period was 14 days and chicks fledged at a

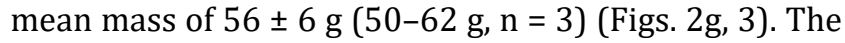
constant growth rate $(K)$ of the nestlings was $0.40 \pm 0.05$ (0.28-0.47) with a growth asymptote of $60.7 \pm 18.9 \mathrm{~g}$ (53.89-71.31 g) (Fig. 4). Daily survival, Mayfield success and apparent success were $100 \%$ for nestling period, assuming chicks remained in the nest for 14 days.
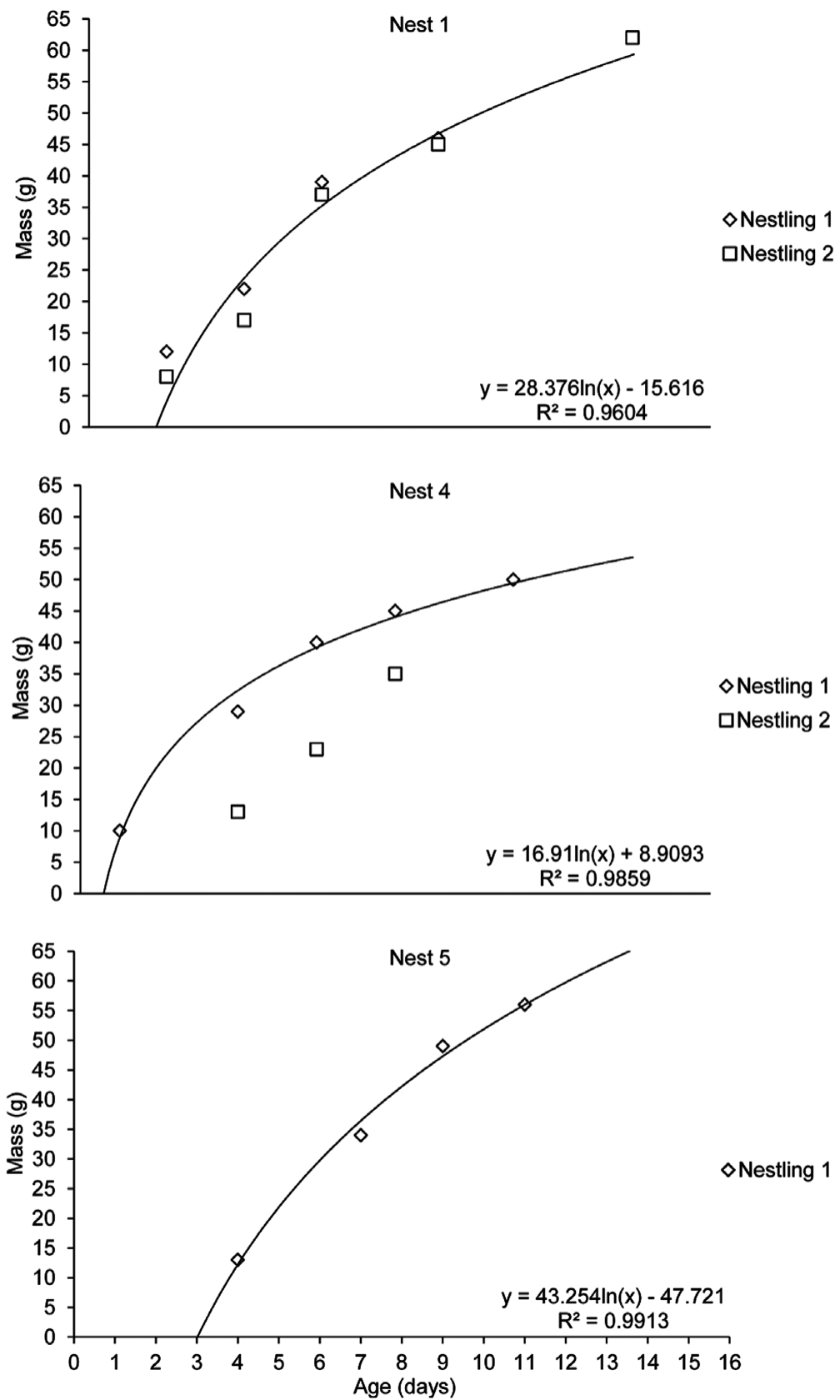

Figure 3. Body mass gain of five nestlings of Leptotila rufaxilla monitored in a forest fragment in southwestern Amazon between 2012 and 2014. The logarithmic equation is based on the most developed chick. 


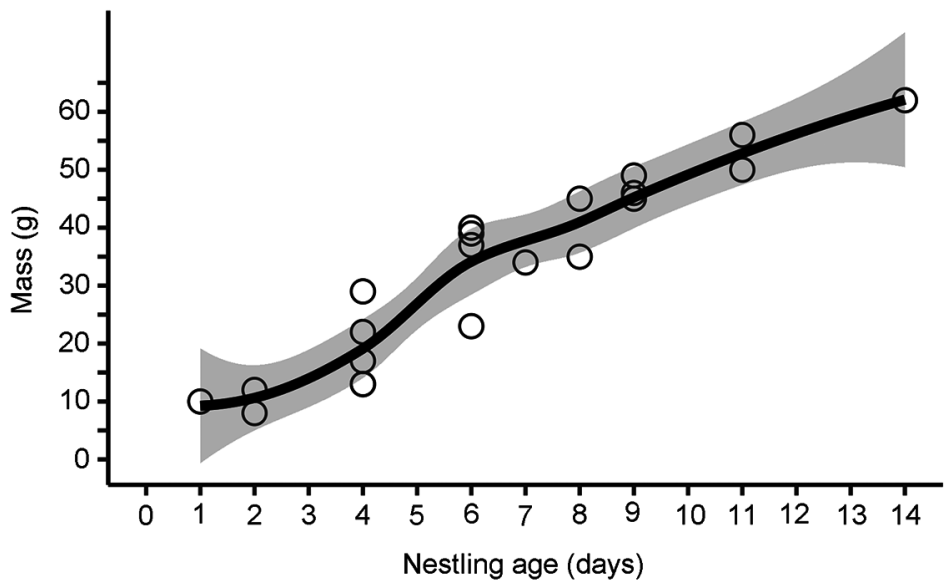

Figure 4. Logistic growth curve for five nestlings of Leptotila rufaxilla, monitored in a forest fragment in southwestern Amazon between 2012 and 2014. Each circle represents a different nestling.

We found active nests in January (2), February (1), August (1) and September (1) (Fig. 5) in ZP. From Brazilian Wikiaves and eBird sites we obtained records of 28 active nests of L. rufaxilla (20 of which contained eggs and eight with nestlings) from ten of the 26 Brazilian states and from French Guiana, Peru and Bolivia between 2005 and 2019. Photographs of active nests were found from all the months of the year except July and August (Fig. 5), although most records were obtained between September-December and February-March $(82.1 \%, \mathrm{n}=23$ ) (Fig. 5). Most the records $(n=14)$ were obtained in Brazil's North and Southeast region, with five from the Northeast, four from Midwest and one from South regions. We obtained two records of nest with eggs and nestlings in French Guiana, one with eggs in both Peru and Bolivia.

\section{Discussion}

Despite Leptotila rufaxilla to be commonly found within the forest (Ingels 1982, Schulenberg et al. 2010), in ZP this species appears to nest in open areas with cultivated plants or in forest edge. Overall, the characteristics of the breeding were similar to those recorded for many
Neotropical Doves (Skutch 1949, Snow \& Snow 1964, Marini et al. 2010, Lima et al. 2019). The shape and dimensions nest of L. r. reichenbachii in Argentina (Bodrati \& Salvador 2013) and L. r. rufaxilla in north Brazil (Oniki \& Willis 1983) were similar to those found in this work, like "shallow platforms". This nest type is typical of many Columbidae, e.g., Geotrygon montana (Ingels 1981), L. verreauxi (Lopes et al. 2013) and Paraclaravis mondetoura (Blomberg 2020). The height of the nests above ground was consistent with descriptions for L. rufaxilla in Argentina (Bodrati \& Salvador 2013, de la Peña 2019), and in French Guiana, where this species as well build its nests in fruit trees or over the accumulation of dry leaves (Tostain 1989).

Eggs and nestling characteristics, as well as the incubation time and nestling period, were all similar to reported in Suriname (Hellebrekers 1942, Ingels 1981), French Guiana (Tostain 1989), Argentina (Bodrati \& Salvador 2013, de la Peña 2019) and for P. mondetou$r a$ in southeastern Ecuador (Blomberg 2020). The sexual dimorphism absent in L. rufaxilla did difficult us to identify if parental care was performed by the male or

the female in ZP.

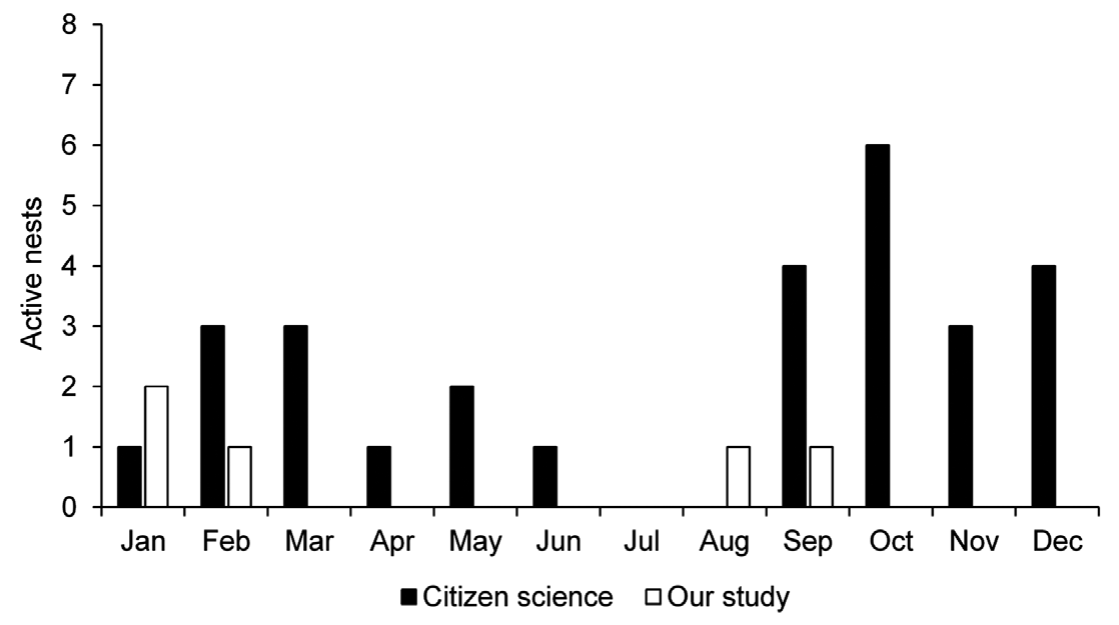

Figure 5. Monthly distribution of 28 active nests of Leptotila rufaxilla in ten Brazilian states between 2010 and 2019, two records in French Guiana in 2011 and 2015, one in both Peru and Bolivia in 2015 
and 2005, respectively. Source: Wikiaves (www.wikiaves com.br) and eBird (www. ebird.org).

However, the alternation on egg incubation and parental care of the chicks was observed in French Guiana (Tostain 1989) as well as for G. montana (Skutch 1949) and P. mondetoura (Blomberg 2020). Regarding the growth rate of nestlings, ours are the first calculations for L. rufaxilla. Our rate was 0.06 lower to the values calculated for four individuals of Columbigallina talpacoti in Suriname, however the growth asymptote was greater (Haverschmidt 1953). Neotropical birds weighing less than $100 \mathrm{~g}$ usually have average values of $K$ around 0.38 (Ricklefs 1976). Therefore, L. rufaxilla with mean weight of 130-178 g (Oniki 1978, Silva et al. 1990, Marini et al. 1997, Piratelli et al. 2001) tends to present values of constant growth rate greater than some Passeriformes (Ricklefs 1976, Oniki \& Ricklefs 1981).

Predation of L. rufaxilla nests has also been observed in French Guiana (Tostain 1989). This author reported that a Black-faced Hawk Leucopternis melanops attacked a nest with two nestlings. Previous study has shown that adult individuals of $L$. rufaxilla were preyed upon by $\mathrm{Mi}$ crastur ruficollis and $M$. semitorquatus falcons in Guatemala (Thorstrom 2000), and this reveals a susceptibility of $L$. rufaxilla to predation in the nest, as well as the young, mainly for inhabiting the interior of the forest, such as these falcons. Open nests tend to be more preyed on near to the edge (Marini 2017) or in open areas in relation into the forest (Oniki 1979, Pestana et al. 2020). Certainly, nests characteristics and nesting site where unfavourable to reproductive success complete of L. rufaxilla in ZP. Nesting success of some Neotropical doves are lower than ours results, in example, in Costa Rica ranging from 22 a 33\% (Skutch 1985). All nestlings from nests sited in the edge of forest in ZP were probably parasitized by Diptera insects such as observed in Trinidadian birds (Dodge \& Aitken 1968). These authors described that $L$. rufaxilla was parasited by maggots of Philornis angustifrons, and two other species, $P$. sanguinis and $P$. downsi for individuals of Leptotila sp. The larvae of these insects also parasitized nestlings of Zenaidura macroura in Louisiana, USA, in which the maggots were scattered over all body surfaces (Glascow \& Henson 1957).

Our data, although few, showed that in the ZP active nests begin to appear in the late dry season, that is, $\mathrm{Au}-$ gust-September, continuing throughout the rainy season (nests in January and February) in Acre (Duarte 2006). That is, that the species begins to reproduce in transition from the dry to the rainy season, extending on through the rainiest months of the year. Photographic records obtained through citizen science showed that this pattern is typical of the rest of Brazil, including the records from French Guiana and Peru. That is, that the species begins to reproduce in transition from the dry to the rainy season (September) in Brazil, extending on through the rainiest months of the year (October-April) (Gan et al. 2004), where most of photographic records were made. When begin reproduction at the end of the dry pe- riod, L. rufaxilla with a diet of fruits and seeds (Wilman et al. 2014), is benefited by the increased availability of both these resources (Haugaasen \& Peres 2005, 2007) in Amazon that guarantees the feeding of the chicks. Previous studies on breeding records of $L$. rufaxilla indicate that this species breeds mainly in the rainy season in French Guiana (Tostain 1989), Suriname (Ingels 1981), Brazil (Oniki \& Willis 1983), and Argentina (Bodrati \& Salvador 2013).

\section{Literature cited}

Baptista LF, Trail PW, Horblit HM, Bonan A, Boesman PFD. 2020. Gray-fronted Dove (Leptotila rufaxilla), version 1.0. In Birds of the World (del Hoyo J, Elliott A, Sargatal J, Christie DA, de Juana E, Editors). Cornell Lab of Ornithology, Ithaca, NY, USA. https://doi.org/10.2173/ bow.grfdov1.01

Bodrati A, Salvador SA. 2013 Nidificación de la Yerutí Colorada (Leptotila rufaxilla reichenbachii) en Misiones, Argentina. Nuestras Aves. 58:85-86.

Blomber C, Greeney HF, Port J. 2020. Observations on the parental care behavior of the Maroon-chested ground Dove (Paraclaravis mondetoura) in southeastern Ecuador. Ornitología Neotropical. 31(1): 57-63.

de la Peña MR. 2019. Aves argentinas: Descripción, comportamiento, reproducción y distribución. Comunicaciones del Museo Provincial de Ciencias Naturales "Florentino Ameghino" (Nueva Serie). (6): 1-334.

Dodge HR, Aitken THG. 1968. Philornis flies from Trinidad (Diptera Muscidae). Journal of the Kansas Entomolical Society. 41(1): 134-154. http://www.jstor.org/ stable/25083688

Duarte AF. 2006. Aspectos da climatologia do Acre, Brasil, com base no intervalo 1971-2000. Revista Brasileira de Meteorologia. 21(3): 308-317.

Gan MA, Kousky VE, Ropelewski CF. 2004. The South America monsoon circulation and its relationship to rainfall over West-Central Brazil. Journal of Climate. 17: 47-66. https://doi.org/10.1175/15200442(2004)017<0047:TSAMCA>2.0.C0;2

Glascow LL, Henson R. 1957. Mourning Dove nestlings infested with larvae of Philornis. The Wilson Bulletin. 69(2): 183-184.

Guilherme E. 2001. Comunidade de Aves do Campus e Parque Zoobotânico da Universidade Federal do Acre, Brasil. Tangara. 1(2): 57-73.

Guilherme E. 2016. Aves do Acre. Ed. Edufac (Editora da Universidade Federal do Acre), Rio Branco. 897 p.

Haugaasen T, Peres CA. 2005. Tree phenology in adjacent Amazonian flooded and unflooded forests. Journal of Tropical Ecology. 37(4): 620-630. https://doi. org/10.1111/j.1744-7429.2005.00079.x

Haugaasen T, Peres CA. 2007. Vertebrate responses to fruit production in Amazonian flooded and unflooded forests. Biodiversity and Conservation. 16: 4165-4190. https://doi.org/10.1007/s10531-007-9217-z

Haverschmidt FR. 1953. Notes on the life history of Columbigallina talpacoti in Surinam. The Condor. 55: 21-25. https://doi.org/10.2307/1364919

Hellebrekers WPhJ. 1942. Revision of the Penard Oölogical collection from Surinam. Zoologische Mededeelingen. 24: 240-275. 
Heming NM, Greeney HF, Marini MÂ. 2013. Breeding biology research and data availability for New World flycatchers. Natureza \& Conservação. 11(1): 54-58. https:// doi.org/10.4322/natcon.2013.009

Ingels J. 1981. Notes on some Surinam birds. Bulletin of the British Ornithologists' Club. 101: 363-370. https://www. biodiversitylibrary.org/item/126877

Ingels J. 1982. Separation in the field of White-fronted and Gray-fronted Doves (Leptotila verreauxi and Leptotila rufaxilla). Bonner Zoologische Beiträge. 33(1): 61-70.

Jahn AE, Bejarano V, Guzmán MB, Brown LM, Provinciato ICC, Cereghetti J, Cueto VR, Giraldo JI, Gómez-Bahamón V, Husak MS, LePage HK, MacPherson M, Marini MÂ, Pizo MA, Quickle A, Roeder DV, Sarasola JH, Tuero DT. 2017. Molt while breeding? Lessons from New World Tyrannus flycatchers. Journal of Ornithology. 158: 10611072. https://doi.org/10.1007/s10336-017-1464-5

Jehle G, Yackel AA, Savidge JA, Skagen SK. 2004. Nest survival estimation: a review of alternatives to the Mayfield estimator. The Condor. 106: 472-484. https://doi. org/10.1093/condor/106.3.472

Lima JM, Guimarães DP, Guilherme E. 2019. Notes on bird breeding activity in a lowland forest in south-west Brazilian Amazonia. Bulletin of the British Ornithologists' Club 139(4): 338-345. https://doi.org/10.25226/ bboc.v139i4.2019.a7

Lopes EL, Peixoto HJC, Hoffmann D. 2013. Notas sobre a biologia reprodutiva de aves brasileiras. Atualidades Ornitológicas. 171: 33-49.

Marini MÂ. 2017. Nesting success of birds from Brazilian Atlantic Forest fragments. Revista Brasileira de Ornitologia. 25(2): 77-83. https://doi.org/10.1007/BF03544381

Marini MÂ, Motta-Junior JC, Vasconcellos LAS, Cavalcanti RB. 1997. Avian body masses from the Cerrado region of central Brazil. Ornitología Neotropical. 8: 93-99.

Marini MA, Borges FJ, Lopes LE, França L, Duca C, Paiva LV, Manica LT, Gressler DT, Heming NM. 2010. Breeding biology of Columbidae in Central Brazil. Ornitología Neotropical 21: 581-590.

Mayfield H. 1961. Nesting success calculated from exposure. The Wilson Bulletin. 73(3): 255-261.

Meneses-Filho LCL, Ferraz PA, Pinha JFM, Ferreira LA, Brilhante NA. 1995. Comportamento de 24 espécies arbóreas tropicais madeireiras introduzidas no Parque Zoobotânico de Rio Branco Acre. Edufac, Rio Branco.

Oniki Y. 1978. Weights, digestive tracts and gonadal conditions of some Amazonian birds. Revista Brasileira de Biologia. 38(3): 79-681.

Oniki Y. 1979. Is Nesting Success of Birds Low in the Tropics? Biotropica. 11(1): 0-69. https://doi. org/10.2307/2388174

Oniki Y, Ricklefs RE. 1981. More growth rates of birds in the humid New World tropics. Ibis. 123: 349-354. https:// doi.org/10.1111/j.1474-919X.1981.tb04038.x

Oniki Y, Willis EO. 1983. A study of breeding birds of the Belém area, Brazil: I. Tinamidae to Columbidae. Ciência \& Cultura. 35(7): 947-956

Oniki Y, Willis EO. 2001. A contagem do número de dias para a incubação e da criação de jovens altriciais no ninho: a importância da padronização. Atualidades Ornitológicas $100(2): 2$.
Pestana GC, Barros EM, Ferreira RG. 2020. The influence of parent body colouration and nesting habitat on bird nest predation. Bird Study. 67(1): 29-34. https://doi.org/1 $0.1080 / 00063657.2020 .1733486$

Piacentini VQ Aleixo A., Agne CE, Maurício GN, Pacheco JF, Bravo GA, Brito GRR, Naka LN, Olmos F, Posso S, Silveira LF, Betini GS, Carrano E, Franz I, Lees AC, Lima LM, Pioli D, Schunck F, Amaral FR, Bencke GA, Cohn-Haft M, Figueiredo LFA, Straube FC, Cesari E. 2015. Annotated checklist of the birds of Brazil by the Brazilian Ornithological Records Committee / Lista comentada das aves do Brasil pelo Comitê Brasileiro de Registros Ornitológicos. Revista Brasileira de Ornitologia 23: 91-298. https://doi.org/10.1007/BF03544294

Piratelli AJ, Melo FP, Caliri RF. 2001. Dados morfométricos de aves de sub-bosque na região leste de Mato Grosso do Sul. Revista Brasileira de Zoologia 18(2): $\quad 305-317 . h t t p s: / / d o i . o r g / 10.1590 / S 0101-$ 81752001000200001

R Development Core Team (2018) R: A language and environment for statistical computing. Vienna: R Foundation for Statistical Computing.

Ricklefs RE. 1967. A graphical method of fitting equations to growth curves. Ecology. 48(6): 978-983. https://doi. org/10.2307/1934545

Ricklefs RE. 1976. Growth rates of birds in the humid New World tropics. Ibis. 118: 179-207. https://doi. org/10.1111/j.1474-919X.1976.tb03065.x

Schulenberg TS, Stotz DF, Lane DF, O'Neill JP, Parker III TA. 2010. Birds of Peru (Revised and Updated Edition). Princeton University Press, New Jersey.

Skutch AF. 1945. Incubation and nesting periods of Central American birds. The Auk. 62(1): 8-37. https://doi. org/10.2307/4079958

Skutch AF. 1949. Life history of Ruddy Quail-Dove. The Condor. 51(1): 3-19. http://www.jstor.org/stable/1364837

Skutch AF. 1985. Clutch size, nesting success, and predation on nests of Neotropical birds, reviewed. Ornithological Monographs. (36): 575-594. https://doi. org/10.2307/40168306

Silva JMC, Lima MFC, Marceliano MLV. 1990. Pesos de aves de duas localidades na Amazônia Oriental. Ararajuba. 1: 99-104.

Silveira M. 1999. Ecological aspects of bamboo-dominated forest in southwestern Amazonia: An ethnoscience perspective. Ecotropica. 5: 213-2016.

Simon JE, Pacheco S. 2005. On the standardization of nest descriptions of Neotropical birds. Revista Brasileira de Ornitologia. 13(2): 143-154.

Snow DW, Snow BK. 1964. Breeding seasons and annual cycles of Trinidad land-birds. Zoologica. 49(1): 1-39.

Souza, J.B.; Guilherme, E.; Cornelius, C. 2020. Integrando fragmentos: Uma proposta de conectividade para duas áreas verdes urbanas do município de Rio Branco. Cap 06. Pp. 85-96. In: Pereira HS, Mariosa PH. (Orgs.). Riscos climáticos e perspectivas ambientais na Amazônia. Editora Appris. Curitiba, PR.

Tewksbury JJ, Anderson JGT, Bakker JD, Billo TJ, Dunwiddie PW, Groom MJ, Hamptom SE, Herman SG, Levey DJ, Machnicki NJ, del Rio CM, Power ME, Rowell K, Salomon AK, Stacey L, Trombulak SC, Wheeler TA. 2014. Natural History's Place in Science and Society. BioScience. 64(4): 300-310. https://doi.org/10.1093/ biosci/biu 032 
Thorstrom R. 2000. The food habits of sympatric forest-falcons during the breeding season in northeastern Guatemala. Journal of Raptor Research. 34(3): 196-202.

Toastain 0. 1989. Phénologie de la reproduction et illustration de la nidification chez les colombes Leptotila rufaxilla et Geotrygon montana en Guyane Française. Alauda. 57(2): 119-131.

Turnhout E, Lawrence A, Turnhout S. 2016. Citizen science networks in natural history and the collective validation of biodiversity data. Conservation Biology. 30(3): 532539. https://doi.org/10.1111/cobi.12696

Wilman H, Belmaker J, Simpson J, Rosa C, Rivadeneira MM, Jetz W. 2014. EltonTraits 1.0: Species-level foraging attributes of the world's birds and mammals. Ecology. 95(7): 2027. https://doi.org/10.1890/13-1917.1

Xiao H, Hu Y, Lang Z, Fang B, Guo W, Zhang Q, Pan X, Lu X. 2017. How much do we know about the breeding biology of bird species in the world? Journal of Avian Biology. 48(4): 513-518. https://doi.org/10.1111/jav.00934

\section{Agradecimientos / Acknowledgments:}

To Conselho Nacional de Desenvolvimento Científico e Tecnológico for providing $J \mathrm{~L}$ and RA with an undergraduate research stipend. To all members of the UFAC ornithology laboratory for support during field work. To Centro Nacional de Pesquisa e Conservação de Aves Silvestres for providing the bands used in project 1099 coordinated by EG.

\section{Conflicto de intereses / Competing interests:}

No potential conflict of interest was reported by the authors.

\section{Rol de los autores / Authors Roles:}

$\mathrm{JL}$ and RA performed data collection, JL and EG wrote the work.

\section{Fuentes de financiamiento / Funding:}

This work was supported by Conselho Nacional de Desenvolvimento Científico eTecnológico (CNPq) [800217/20136; 800249/20143].

\section{Aspectos éticos / legales; Ethics / legals:}

Observational information did not require permits specific. Authors declare that they did not violate or omit ethical or legal norms in this research. 